\title{
Factors Associated to The Prevalence of Low Birth Weight in Dr. Doris Sylvanus Hospital Palangka Raya 2018
}

\author{
Prinawati $^{*}$, Roselina Panghiyangani ${ }^{* *}$, Syamsul Arifin ${ }^{* * *}$, Husaini $^{* * * * *}$, Meitria Syahadatina Noor ${ }^{* * * * *}$ \\ * Master of Public Health, Faculty of Medicine, Lambung Mangkurat University, Indonesia \\ ** Department of Biomedicine, Faculty of Medicine, Lambung Mangkurat University, Indonesia \\ *** Department of Public Health, Faculty of Medicine, Lambung Mangkurat University, Indonesia \\ **** Master of Public Health, Faculty of Medicine, Lambung Mangkurat University, Indonesia \\ ***:** Department of Public Health, Faculty of Medicine, Lambung Mangkurat University, Indonesia \\ DOI: 10.29322/IJSRP.10.08.2020.p104121 \\ http://dx.doi.org/10.29322/IJSRP.10.08.2020.p104121
}

\begin{abstract}
Low Birth Weight Babies (LBW) is the weight of a baby born less than 2,500 grams regardless of gestational age and occurs in infants less than (37 weeks) of pregnancy age. In 2015, there were $15.5 \%$ LBW incidence, meaning that 20.6 million LBW infants were born every year and $96.5 \%$ of them were in developing countries. This research aims to analyze parity, gestational age, pregnancy complications, anemia, and education related to the incidence of low birth weight babies in dr. Doris Sylvanus Hospital Palangka Raya in 2018. The research is analytical observational research with a case-control research design. Samples of 168 medical record data with case and control comparisons are 1: 1 , which is a minimum of $84: 84$. The sampling technique uses purposive sampling method. The research instrument used a checklist. Data analysis with descriptive and statistical analysis, i.e., chi-square and multiple logistic regression. Factors associated with LBW events were parity $(\mathrm{p}=0.009)$, gestational age $(\mathrm{p}=0.000)$, pregnancy complications $(\mathrm{p}=0.045)$, anemia $(\mathrm{p}=0.039)$. The results of multiple logistic regression analysis showed age of gestation ( $\mathrm{p}=0.000$; Exp. $\mathrm{B}=6.073)$, and parity ( $\mathrm{p}=0.016$; Exp. $\mathrm{B}=2.320$ ) with $95 \%$ confidence level. There was a relationship of gestational age and parity with LBW. The most dominant variable is the age of the pregnancy.
\end{abstract}

Index Terms- parity, gestational age, pregnancy complications, anemia, education, LBW

\section{INTRODUCTION}

$\mathrm{O}$ ne of the main factors in increasing infant mortality (IMR) is the increased incidence of Low Birth Weight Babies (LBW) (1). LBW is the weight of a baby born less than 2,500 grams regardless of gestation or gestational age and occurs in infants less than months (less than 37 weeks) gestational age or at term (2). According to WHO, in 2015 there were $15.5 \%$ LBW incidence, meaning that 20.6 million LBW infants were born every year, and $96.5 \%$ of them were in developing countries. Indonesia is a developing country that ranks third in the highest prevalence of LBW (11.1\%) after India (27.6\%) and is also the second country with the highest prevalence of LBW in ASEAN after the Philippines (3).

LBW has a high risk of mortality and morality in neonates, especially in the first month of life (4). LBW events will have an impact on the health of infants both at the time the baby is born and at the time of its development in the future, such as the risk of experiencing cardiovascular disease, diabetes mellitus, and mental development disorders (5). Factors related to LBW events include maternal factors such as maternal age, birth distance, previous LBW history, gestational age, the presence of chronic diseases (anemia, hypertension, diabetes mellitus), fetal factors such as hydramion, multiple pregnancies, congenital defects, and placental factors such as reduced placental weight or cellularity, reduced surface area, placental detachment (6).

In 2018 in Indonesia, the proportion of birth weight less than 2,500 grams was 6.2\% , and in Central Kalimantan Province, the proportion of birth weight less than 2,500 grams was 5.8\% (7). LBW incidence in Central Kalimantan Province in 2017, the number of LBW occurrences was 797 cases, and the number was higher compared to the number of LBW in 2016 as many as 645 cases (8). Based on data obtained from dr. Doris Sylvanus Hospital Palangkaraya 2016, the number of LBW as much as $299(17.8 \%)$ cases and increased the number of LBW in 2017 to 307 (19.5\%) cases (9). Based on the study of the problems above, the research will be conducted to analyze the factors associated with the incidence of Low Birth Weight Babies in dr. Doris Sylvanus Hospital Palangka Raya in 2018.

\section{RESEARCH METHOD}

The study begins by determining the case of pregnant women giving birth to Low Birth Weight Babies (LBW) and determining control that is pregnant women who give birth to Normal Birth Weight Babies. Then they were traced retrospectively whether there are risk factors seen from risk parity, gestational age, complications of pregnancy, anemia, and education. The design of this study was used to determine the factors associated with the prevalence of Low Birth Weight in dr. Doris Sylvanus Hospital Palangka Raya. This study uses secondary data from medical records and registers using checklist sheets as a tool for data 
collection. The population in this study were all mothers with babies born alive at dr. Doris Sylvanus Hospital Palangka Raya. The sampling technique in this study was purposive sampling

\section{FINDINGS}

Table 1. Univariate Analysis of Research Variables

\begin{tabular}{llcccc}
\hline \multicolumn{1}{c}{ Variable } & \multirow{2}{*}{ Category } & \multicolumn{4}{c}{ Frequency } \\
\cline { 3 - 6 } Parity & & Case & $\mathbf{\%}$ & Control & \% \\
\cline { 2 - 6 } & Risky & 54 & 64.3 & 36 & 42.9 \\
\cline { 2 - 6 } & No risk & 30 & 35.7 & 48 & 57.1 \\
\hline Age of & Less age & 49 & 58.3 & 15 & 17.8 \\
\cline { 2 - 6 } Pregnancy & Enough & 35 & 41.7 & 69 & 82.2 \\
\hline Pregnancy & Yes & 47 & 55.9 & 33 & 39.3 \\
Complications & No & 37 & 44.1 & 51 & 60.7 \\
\hline Anemia & Yes & 39 & 46.4 & 25 & 29.8 \\
\cline { 2 - 6 } & No & 45 & 53.6 & 59 & 70.2 \\
\hline \multirow{2}{*}{ Education } & Low & 29 & 34.5 & 27 & 32.1 \\
\cline { 2 - 6 } & High & 55 & 65.5 & 57 & 67.9 \\
\hline
\end{tabular}

Table 2. Bivariate Analysis with Chi-Square Test

\begin{tabular}{|c|c|c|c|c|c|c|}
\hline \multirow{3}{*}{ Variable } & \multicolumn{4}{|c|}{ LBW Prevalence } & \multirow{3}{*}{$\begin{array}{c}\mathrm{p}- \\
\text { value }\end{array}$} & \multirow[t]{3}{*}{ OR } \\
\hline & \multicolumn{2}{|c|}{ LBW } & \multicolumn{2}{|c|}{ Normal } & & \\
\hline & $\mathbf{n}$ & $\%$ & $\mathbf{n}$ & $\%$ & & \\
\hline \multicolumn{7}{|l|}{ Parity } \\
\hline Risky & 54 & 64.3 & 36 & 42.9 & \multirow[t]{2}{*}{0.009} & \multirow[t]{2}{*}{2.400} \\
\hline No risk & 30 & 35.7 & 48 & 57.1 & & \\
\hline \multicolumn{7}{|c|}{ Age of Pregnancy } \\
\hline Less age & 49 & 58.3 & 15 & 17.8 & \multirow[t]{2}{*}{0.000} & \multirow[t]{2}{*}{6.440} \\
\hline Enough & 35 & 41.7 & 69 & 82.2 & & \\
\hline \multicolumn{7}{|c|}{ Pregnancy Complications } \\
\hline Yes & 47 & 55.9 & 33 & 39.3 & \multirow[t]{2}{*}{0.045} & \multirow[t]{2}{*}{1.963} \\
\hline No & 37 & 44.1 & 51 & 60.7 & & \\
\hline \multicolumn{7}{|l|}{ Anemia } \\
\hline Yes & 39 & 46.4 & 25 & 29.8 & \multirow[t]{2}{*}{0.039} & \multirow[t]{2}{*}{2.045} \\
\hline No & 45 & 53.6 & 59 & 70.2 & & \\
\hline \multicolumn{7}{|l|}{ Education } \\
\hline Low & 29 & 34.5 & 27 & 32.1 & \multirow[t]{2}{*}{0.870} & \multirow[t]{2}{*}{1.113} \\
\hline High & 55 & 65.5 & 57 & 67.9 & & \\
\hline
\end{tabular}

Based on table 2 above, it is known that there are variables that have a relationship with LBW in dr. Doris Sylvanus Hospital Palangka Raya, namely parity ( $\mathrm{p}$-value $=0.009$ ) with an OR value of 2.400, gestational age ( $\mathrm{p}$-value $=0.000)$ with an $\mathrm{OR}$ value of 6.440 , pregnancy complications ( $\mathrm{p}$-value $=0.045$ ) with an $\mathrm{OR}$ value of 1.963 , and anemia ( $\mathrm{p}$-value $=0.039$ ) with an OR value of 2.045 while the variables that have no relationship with LBW are education ( $\mathrm{p}$-value $=0.870$ ).

Table 3. Multivariate Analysis with Logistic Regression Test

\begin{tabular}{lcccc}
\hline Independent & p-value & $\begin{array}{c}\text { Exp } \\
\text { Variable }\end{array}$ & & \multicolumn{2}{c}{$\mathbf{9 5 \%}$ CI } \\
\cline { 4 - 5 } & & Lower & Upper \\
\hline Parity & 0.016 & 2.320 & 1.166 & 4.614 \\
\hline Age of Pregnancy & 0.000 & 6.073 & 2.923 & 12.620 \\
\hline
\end{tabular}

\begin{tabular}{lllll}
\hline $\begin{array}{l}\text { Pregnancy } \\
\text { Complications }\end{array}$ & 0.367 & 1.373 & .689 & 2.738 \\
\hline
\end{tabular}

Based on the table above, it can be seen that the most dominant variable has a relationship with LBW in dr. Doris Sylvanus Hospital Palangka Raya, namely gestational age $(\mathrm{p}$-value $=0.000)$ with $\operatorname{Exp}(B)$ value of 6.073. Pregnant women with the age of the pregnancy for preterm had chances 6.073 times more likely to give birth to low birth weight babies than pregnant women with gestational age term

\section{DISCUSSION}

Based on table 1 above, it is known that in the case group, the majority of respondents $(64.3 \%)$ had risk parity while in the control group (57.1\%), the majority of respondents had no risk parity. Risky parity of LBW is parity one and then decreased at parity 2 or 3 , then rose again in parity 4 (10). At zero parity or primigravida, the risk of a mother experiencing pre-eclampsia and eclampsia, which tends to cause pregnancy, should be terminated, thereby increasing the risk for premature birth. In contrast, mothers with parity of more than three are at risk of changing the uterus due to repeated pregnancy causing damage to blood vessels in the wall the uterus, which affects the circulation of nutrients to the fetus (11).

Based on table 1 above, it is known that in the case group, the majority of respondents (58.3\%) gave birth to LBW babies with a gestational age of less than months while in the control group, the majority of respondents $(82.2 \%)$ gave birth to normal babies with a gestational age of the pregnancy. Under the drain of pregnancy affect the maturation of the organ and the effectiveness of the distribution of nutrients and oxygenation of the fetal placenta needed for optimal growth (12). Age pregnancy preterm ( $<37$ weeks) causes fetal growth and development have not been optimal so that the risk of babies born weighing less than 2,500 grams.

Based on table 1 above, it is known that in the case group, the majority of respondents (55.9\%) experienced pregnancy complications while in the control group, the majority of respondents (60.7\%) did not experience pregnancy complications. Complications about signs and symptoms experienced during pregnancy include pre-eclampsia, eclampsia, anemia, premature rupture of membranes, diabetes mellitus, heart disease, placenta previa, placental abruption, polyhydramion (13). Mothers who are experiencing pregnancy diseases, such as infectious and noninfectious diseases, will endanger the condition of the mother and fetus. The disease can disrupt the process of metabolic physiology and gas exchange in the fetus, which results in premature birth so that the risk of LBW (14).

Based on table 1 above, it is known that in the case group, the majority of respondents $(46.4 \%)$ experienced anemia in pregnancy while in the control group, the majority of respondents (70.2\%) did not experience anemia. The lack of Hb levels causes the blood not to be able to send enough oxygen to all tissues so that the metabolic process and the exchange of important nutrients in the tissues are disrupted and the lack of food supply to the products of conception through the placenta (15). This condition 
inhibits the growth and development of the fetus, causing LBW birth.

Based on table 1 above, it is known that in the case group and the control group, the majority of respondents $(65.5 \%$ and $67.9 \%$ ) with high education. The higher the level of education, the insight possessed by the mother will be higher and have an open mindset to receive new knowledge that is considered useful in her pregnancy (16).

LBW is the weight of a baby born less than 2,500 grams regardless of gestation or gestational age and occurs in infants less than months (less than 37 weeks) gestational age or at term. LBW is very susceptible to illness because its characteristics are not yet mature. Babies with LBW have a higher risk of death, growth retardation, and development during childhood compared to babies who are not LBW (17). Factors related to LBW include maternal factors such as maternal age, birth distance, previous LBW history, gestational age, the presence of chronic diseases (anemia, hypertension, diabetes mellitus), fetal factors such as hydramion, multiple pregnancies, congenital defects, and placental factors such as reduced placental weight or cellularity, reduced surface area, placental detachment.

There are several risk factors associated with LBW in dr. Doris Sylvanus Hospital Palangka Raya, namely parity (pvalue $=0.009), \quad$ gestational age $(\mathrm{p}$-value $=0.000)$, pregnancy complications $(\mathrm{p}$-value $=0.045)$, and anemia $(\mathrm{p}$-value $=0.039)$. This is in line with the theory of Prawirohardjo (2014), which says that the first parity is risky because the uterus is the first time to receive the results of conception and the flexibility of the uterine muscles is still limited for fetal growth. While mothers with parity more than 3 have high maternal numbers because endometrial disorders can occur due to repeated pregnancy. This study is consistent with research conducted by Triana (2014), which says that the mother pregnant who have a variety of diseases accompanying pregnancy is at risk of having low birth weight. The disease can interfere with the physiological processes of metabolism and gas exchange in the fetus, which results in premature birth so that the risk of LBW. In line with research conducted by Mahayana (2015), which states that there is a significant relationship between anemia and LBW, this occurs because of the disruption of intrauterine fetal growth and preterm labor.

Risk factors associated with the most dominant LBW's mother was pregnant with the age of the pregnancy for preterm (pvalue $=0.000$ ) with a value of $\operatorname{Exp}(B) 6.073$. This means that pregnant women with the age of the pregnancy for preterm $(<37$ weeks) have a chance of 6.073 times more likely to give birth to low birth weight babies than women who just months. This is in line with research conducted by Septiani (2018), which states that there is a relationship between gestational age and LBW events. Supported also by research conducted by Sholiha (2015) based on the results of logistic regression shows that gestational age is a dominant risk factor with LBW with p-value $=0.000$ and OR 66, meaning that mothers with less gestational age have a 66 times greater risk of giving birth to babies LBW compared to women with gestational age.

\section{CONCLUSION}

Based on the results of research and discussion, it can be concluded as follows:

1. There is no relationship between education and low birth weight in dr. Doris Sylvanus Hospital Palangka Raya.

2. There is a relationship between parity, gestational age, pregnancy complications, and anemia with low birth weight in dr. Doris Sylvanus Hospital Palangka Raya.

3. The age of pregnancy is the most associated with the incidence of low birth weight in dr. Doris Sylvanus Hospital Palangka Raya.

\section{REFERENCES}

1. Rustina. (2015) Premature Babies: Nursing Perspectives. Segung Seto Jakarta

2. Saputra, Lyndon. (2014) Care of Neonates for Babies. Bina Aksara Tangerang.

3. Supiati (2016) Mother's Characteristics about Low Birth Weight Baby Incidence. Journal of Traditional Midwifery and Health. 1 (1); 1-99

4. Ministry of Health Republic of Indonesia. (2015) Indonesia Health Profile 2014. Ministry of Health Republic of Indonesia. Jakarta

5. Mitra. (2014) Low Birth Weight Solutions and Their Impacts. Journal of Community Health. 2 (5); 191-192

6. England., C. (2014) The Healthy Low Birth Weight Baby, in Myles Textbook for Midwives. 617-627. Churchill Livingstone Elsevier

7. Ministry of Health Republic of Indonesia. (2018) Basic Health Research Health Research and Development Agency. Jakarta

8. Central Kalimantan Provincial Health Office. (2018) Health Profile of the Province of Central Kalimantan in 2017.

9. Hospital Medical Records dr. Doris Sylvanus Palangka Raya in 2018.

10. Nursusila, Majid, R. (2017) Risk Factors for Low Birth Weight (LBW) in the General Hospital of Southeast Sulawesi Province 2016. 2016. Scientific Journal of Public Health Students. 2 (6); 1-12

11. Walyani, SE. (2015) Midwifery Care in Pregnancy. New Library. Yogyakarta

12. Kumalasari, I., Tjekyan, S., Zulkarnain. (2018) Risk Factors and Low Birth Weight (BBLR) at RSUP DR. Mohammad Hoesin Palembang in 2014. Journal of Public Health Sciences . 9 (1); 41-52

13. Prawirohardjo, S. (2016) National Reference Book on Maternal and Neonatal Health. Library Development. Jakarta.

14. Triana, A. (2014) Effects of Concomitant Pregnancy and Multiple Pregnancy Diseases with Low Birth Weight Babies in Arifin Achmad Regional Hospital in Riau Province. Journal of Community Health. 2 (5); 193-198

15. Suwarni, Y., Noor, MS, Rahayu, A. (2016) Relationship between Parity, MUAC, $\mathrm{Hb}$ Levels and Age of Pregnant Women with Birth Weight of Babies. Journal of Indonesian Public Health Publications. 1 (1); 60-65

16. Jayanti, FA., Dharmawan, Y., Aruben, R. (2017). Factors Associated with the Incidence of Low Birth Weight in the Work Area of the City Health Center Bangetayu Semarang. Journal of Public Health. 5 (4); 812-822

17. Rajashree, K. (2015) Study on the Factors Associated with Low Birth Weight among Newborns delivered in a Tertiary-Care Hospital, Shimoga, Karnataka. International Journal of Medical Science and Public Health. e-journal 4 (9); $1287-1290$

\section{AUTHORS}

First Author - Prinawati, Master of Public Health, Faculty of Medicine, Lambung Mangkurat University, Indonesia.

Second Author - Roselina Panghiyangani, Department of Biomedicine, Faculty of Medicine, Lambung Mangkurat University, Indonesia.

Third Author - Syamsul Arifin, Department of Public Health, Faculty of Medicine, Lambung Mangkurat University, Indonesia. 
Fourth Author - Husaini, Master of Public Health, Faculty of Medicine, Lambung Mangkurat University, Indonesia.

Fifth Author - Meitria Syahadatina Noor, Department of Public Health, Faculty of Medicine, Lambung Mangkurat University, Indonesia.
Correspondence Author - Prinawati, Master of Public Health, Faculty of Medicine, Lambung Mangkurat University, Indonesia, email: prinawatie007@gmail.com 